\title{
Evaluating integrated assessment models of global climate change - From philosophical aspects to practical examples
}

\author{
Author: Valeria Jana Schwanitz \\ Institute: Western Norway University of Applied Sciences \\ Corresponding author: Valeria Jana Schwanitz, valerias@hvl.no \\ Last update: September, 5th, 2021
}

Abstract: Integrated Assessment Models of Global Climate Change are an established tool to explore possible pathways of climate change mitigation and adaptation. The models are a quantitative backbone for IPCC reports. But can the models be trusted? This manuscript discusses how the models can be scrutinized and where limits to model validation exist.

\section{Why is validation impossible?}

Integrated Assessment Models of Global Climate Change (short: IAM) are an established tool to explore possible pathways of climate change mitigation and adaptation. An example is the recently developed scenario family of Shared-Socio Economic Pathways (O'Neill et al. 2016), for which different IAM were used to complement scenario narratives with quantitative model results (Riahi et al. 2017). With their potential to highlight inter-linkages between climate, energy, land-use, and economic development, IAMs are a modeling backbone of Assessment Reports of the Intergovernmental Panel of Climate Change and they are widely used to guide the development of policy road maps to cope with identified challenges (e. g. the EU Strategy for 2050 "A clean planet for all", $\operatorname{COM(2018)).~Thus,~it~is~important~to~scrutinize~the~models~and~to~test~their~applicability.~In~}$ other words, a model that has been validated can be applied with confidence.

Commonly, validation refers to the accuracy of a model and its ability to represent the real system (e. g. Sargent 2003). To understand what this means for IAM requires a clear definition of the purpose of the models. IAM comprise different modules that describe relevant parts of the earth system in varying detail, which are commonly the energy system, an economic growth component, the climate system and the land-use system. In comparing alternative transformation pathways with the business-as-usual case or reference scenario, IAM strive to understand the causes and drivers for relative quantitative changes that are observed in model output variables, such as sectoral greenhouse gas emission trajectories, investments into the energy system or the fuel mix in a model region. Therefore, the purpose of IAM is neither forecasting nor prediction. Instead, the models are built to study what-if questions aiming at solving the global climate change problem.

However, the study of the coupled human-nature system at the global level poses two fundamental difficulties for validation:

1. There is unsolvable uncertainty and knowledge about the total system is incomplete.

2. Counterfactuals from controlled experiments do not exist.

The first difficulty relates to what is known as the problem of "open systems": Due to the complexity of the earth system, it is impossible to perfectly mimic the same in any model. Therefore, modelers are faced with a choice over which processes and scales to include in an IAM and which to omit. Obviously, modeling teams disagree and the result is that models differ in many respects (from modeling paradigms to parameter choices). In the hypothetical case where computational power is sufficient to simulate the earth system in all its complexity, scientists would still fail to construct an accurate model for two reasons. First, many processes that govern 
the earth system are non-linear, which implies unsolvable uncertainty in principle. Second, our knowledge is incomplete, because fundamental laws and processes that govern the earth system are largely unknown. An obvious example of incomplete knowledge is human behavior and its impact on the direction and speed of technological change. Moreover, the problem of incomplete knowledge is amplified by the fact that the models are set up to study future scenarios. Yet, the future is also unknowable in principle. The past also poses difficulties because IAM rely on a variety of historical data, some of which are better known than others, but uncertainties remain high for different reasons.

The second fundamental problem about the absence of counterfactuals is a direct consequence of the first. In theory, one would need to replicate the earth for conducting an experiment and obtaining observational data; or - if scrutinizing isolated questions - one would ideally need to run a controlled experiment. While the former experiment is hypothetical, the latter can even bring up moral issues since it involves humans (c. f. the experiences from running the experiment "Biosphere II" and the causes for its failure, Poynter 2006). Moreover, the most valuable counterfactuals would only be generated after decades, since the modeling period of IAM typically lasts decades running until the year 2100 .

Therefore, compromises are necessary when it comes to the question of validating IAM (Schwanitz 2013). The task is to establish scientific legitimacy of the model by defending the choice of prioritization and by providing the rationales for including or omitting important processes. In addition, models need to be tested systematically to justify their intended use.

Even though validation of IAMs in a strict sense is impossible, the models can be scrutinized and their applicability can be tested in various ways. After all, the key question is not "How to validate Integrated Assessment Models of Climate Change?" Instead the key question is "Does the model perform well enough for its intended use?" Models that can be applied with confidence have shown structural validity and - to the extent possible - behavioral validity (Schwanitz 2013, Wilson et al. 2017). The former implies that the model is an accurate representation of the system response being modeled, allowing modelers to observe the right results for the right reasons. In contrast, behavioral validity means that modeled outcomes are consistent with available observational data.

By emphasizing "evaluation" over "validation", I stress that the problems of testing IAM are fundamental and unsolvable. Preferring "evaluation" over "validation" semantically acknowledges that "emphasizing validation deceives society with the impression that, by expending sufficient effort, uncertainty can be eliminated and absolute knowledge be attained" (Konikow and Bredehoeft 1992). Only through transparency can trust (and hence confidence) into the models be built. The remainder of this article discusses the evaluation portfolio for IAMs, followed by an example and a final note of caution.

\section{How to evaluate IAM?}

An evaluation exercise strives to answer the question "Does the model perform well enough for its intended use?" It starts with the definition of the purpose of the model and its relation to the evaluation exercise. Exercises can take the form of narrow exercises that focus on a particular question. Examples are the evaluation of the representation of variable renewable energies as reported in Pietzker et al. 2017, and that of Sluisveld et al. 2018, which examined the rate of change for energy technologies. However, it is not enough to undertake only selected tests. The models also need to pass through regular systematic tests. Here the task is to test the model as a 
whole and in all parts; i.e. model input, output, and the structure and behavior of its components. Systematic tests are most valuable if community-wide standards are followed. However, such an evaluation framework does not currently exist in the IAM community. In this regard, experience from the climate modeling community can be used (Wilson et al. 2017). A systematic IAM evaluation framework has been proposed in Schwanitz et al. 2013.

The evaluation framework for IAM comprise of loops that differ in intensity of traversing them. The full cycle includes setting up an evaluation framework (which includes an agreement on when to reject the model or its version), scrutiny of the conceptual model, code verification, model calibration, model documentation, model performance tests, uncertainty and sensitivity analysis, documentation of the evaluation process, as well as communication to stakeholders (see Figure 1).

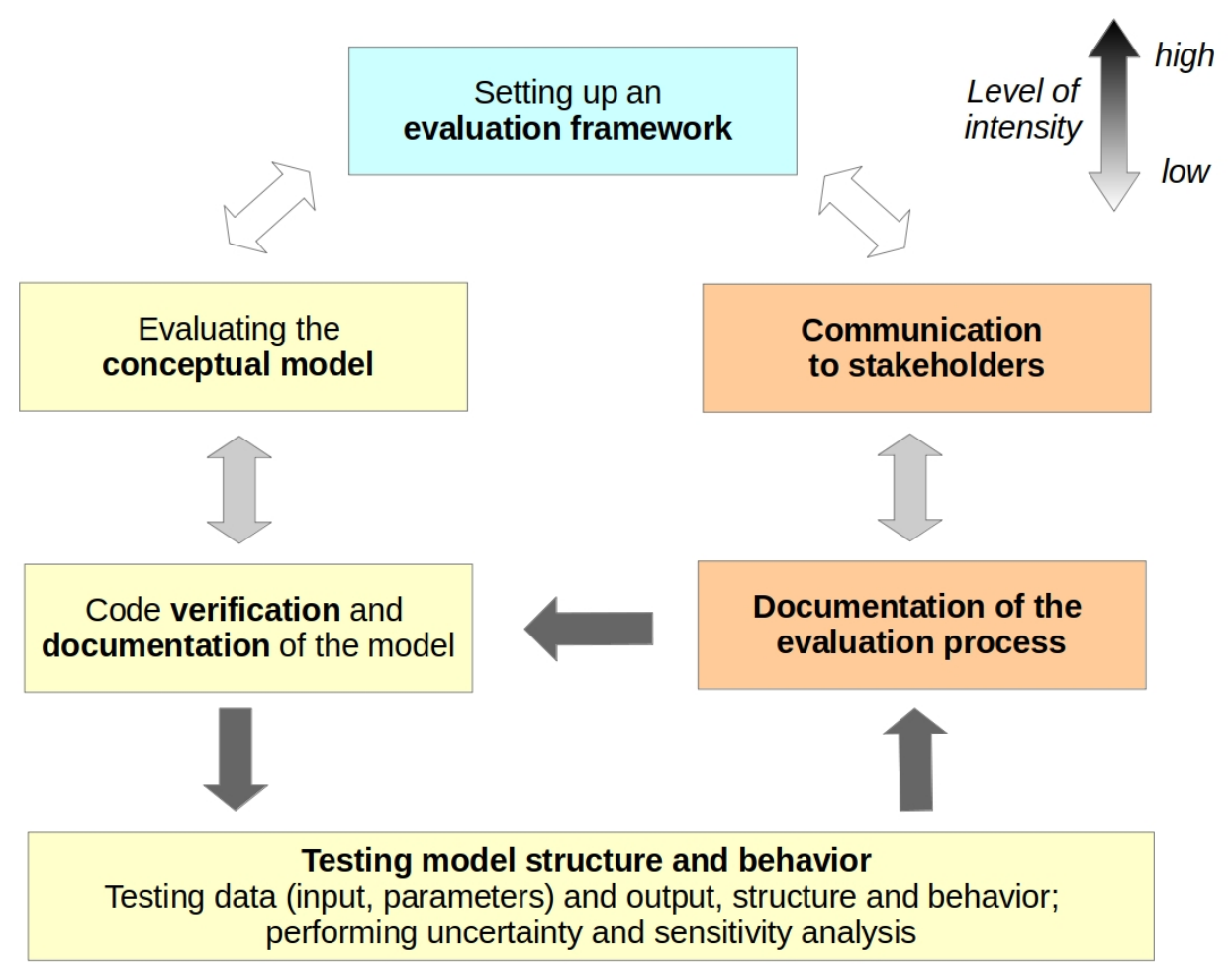

Figure 1 : Evaluation framework for IAM

Source: based on Schwanitz et al. 2013

Due to the fundamental difficulties with evaluating IAM as discussed in the previous section, it is important to carry out as many different tests as possible. The focus is on testing the structural validity of the model. The key questions are: Is the model a sufficiently accurate representation of the system response being modeled?, and: Are the right results observed for the right reasons? Also, to the extent possible, behavioral validity should be tested by assessing whether modeled outcomes are consistent with available experimental data. The various tests can be performed by different parties. In addition to the modelling teams themselves, the models can be evaluated by third parties, e.g., domain experts and even stakeholders.

The portfolio of evaluation options includes (see also Figure 2):

- A comparison of model results with observational data, e. g. against historical data and projected dynamics, stylized historical patterns, near-term observations, and experimental data; 
- A comparison of model results with results of other models, e. g. as done in Multi-model Intercomparison Projects (known as MIP), diagnostics experiments, and testing of model hierarchies;

- A comparison of tests performed by different parties; e.g. individual modelers, team, community, external experts, users.

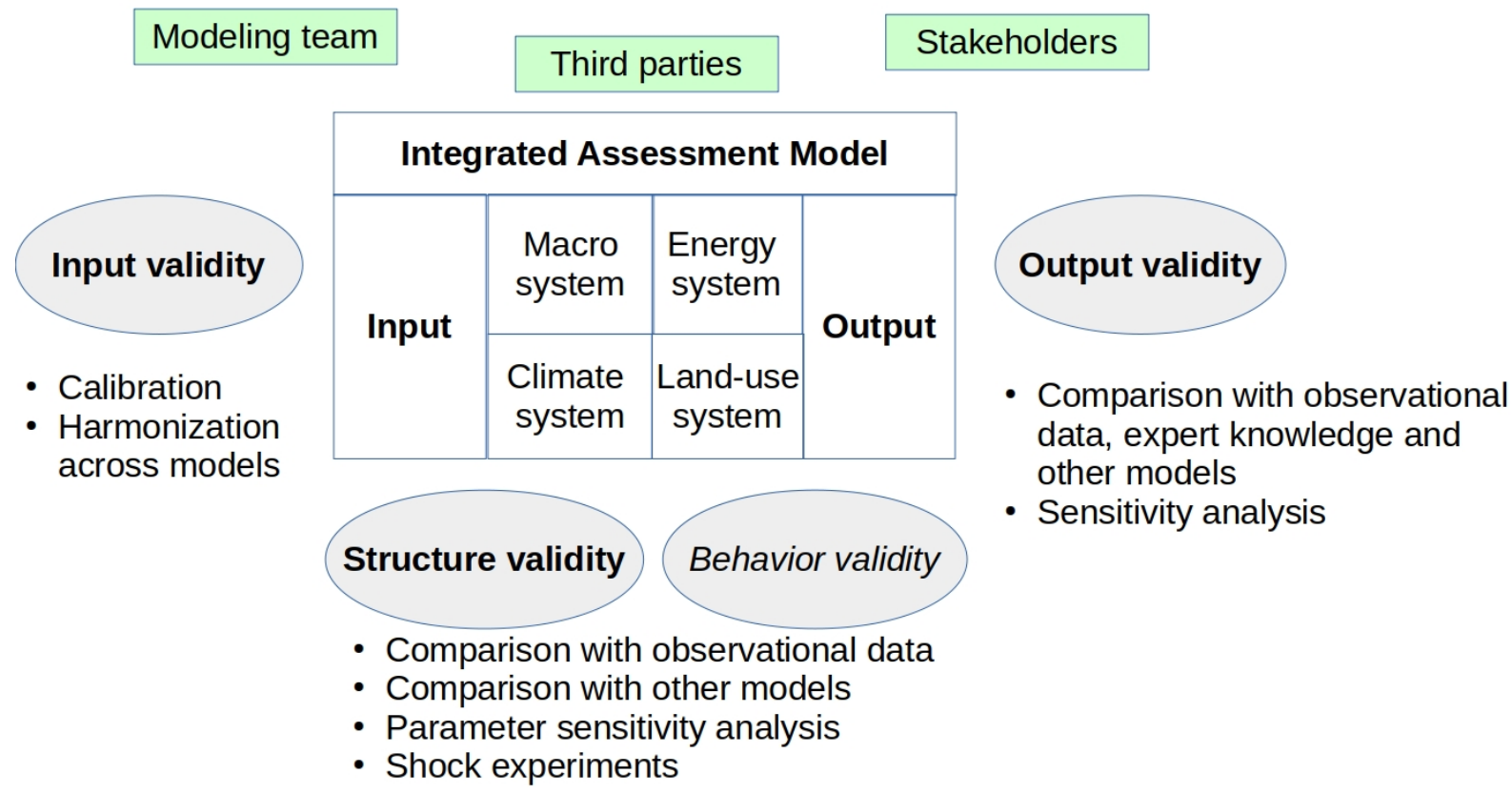

Figure 2 : Evaluation portfolio

Source: based on Schwanitz et al. 2013 and Wilson et al. 2017

\section{An example of an evaluation exercise and a note of caution}

\subsection{Are offshore wind scenarios in IAM realistic?}

Technological change is a crucial process in IAM because it determines the future energy mix in different scenarios, which are a key model output. An important driver of the future energy mix is the anticipated development of relative costs for the deployment of single energy technologies. Levelized Costs of Electricity (short: LCOE) are a tool to compare the costs of different energy technologies occurring over the lifetime of a respective power plant relative to its energy production. LCOE account for investment costs, the costs for operation and maintenance, and the capacity factor of the power plant as well as its lifetime. Having said this, we now look into the development of LCOE for offshore wind technology anticipated in different IAM to illustrate the idea of an evaluation exercise. I utilize data published in Luderer et al. 2017.

There are four different IAM that cover the development of offshore wind technology explicitly in Luderer et al. 2017. These models are IMAGE (developed by PBL, Netherlands Environmental Agency), MESSAGE (developed by the International Institute for Applied Systems Analysis in Austria), POLES (developed by the consultancy Enerdata in collaboration with the European Commission's Joint Research Center IPTS and the University of Grenoble-CNRS in France) and WITCH (developed by the European Institute on Economics and the Environment in Italy). Table 1 presents an overview of these models, which differ in their general modeling approach (e. g. recursive-dynamic partial equilibrium vs. temporal optimization general equilibrium model) as well as in the modelling of technological change and the buildup of offshore wind capacities over the running period of the model, among other aspects. 


\begin{tabular}{|c|c|}
\hline Model and type of model & $\begin{array}{l}\text { Assumptions for the deployment of offshore wind } \\
\text { technology }\end{array}$ \\
\hline \multicolumn{2}{|c|}{$\begin{array}{l}\text { IMAGE } \\
\text { Sources of documentation: Junginger et al. 2010; Gernaat et al. } 2014\end{array}$} \\
\hline $\begin{array}{l}\text { Recursive dynamic partial } \\
\text { equilibrium model, simulation } \\
\text { with imperfect foresight }\end{array}$ & $\begin{array}{l}\text { Endogenous technological change, energy technologies } \\
\text { compete on LCOE in a multinomial logit. } \\
\text { Based on a sample of } 15 \text { offshore wind farms, the cost of six } \\
\text { different power plant classes as a function of sea depth and } \\
\text { distance to shore are estimated. Investment costs decrease } \\
\text { with a learning rate of } 7 \% \text {. This assumption is based on a } \\
\text { sample of major completed or projected offshore wind farms } \\
\text { during } 1991-2012 \text {. Costs for operation and maintenance are } \\
\text { assumed to make up } 15 \% \text { of the capital costs. Capacity } \\
\text { factors range between } 9-50 \% \text {. } 20 \text { years lifetime, } 10 \% \text { interest } \\
\text { rate. }\end{array}$ \\
\hline \multicolumn{2}{|c|}{$\begin{array}{l}\text { MESSAGE } \\
\text { Source of documentation: Johnsen et al. 2017, Fricko et al. 2017, } \\
\text { http://data.ene.iiasa.ac.at/message-globiom/macro.html }\end{array}$} \\
\hline $\begin{array}{l}\text { Partial equilibrium energy system } \\
\text { with soft-coupling to } \\
\text { macro-economic growth model, } \\
\text { intertemporal optimization with } \\
\text { perfect foresight, linear } \\
\text { representation of the energy } \\
\text { system }\end{array}$ & $\begin{array}{l}\text { Exogenous technological change. Electricity is a uniform good } \\
\text { and technologies compete linearly on an LCOE basis. } \\
\text { Technology cost developments follow scenario narratives. } \\
\text { There are across-the-board cost reductions for "non-bio } \\
\text { renewables"of } 10-30 \% \text { (low technology improvement case) } \\
\text { and up to } 90 \% \text { (high technology improvement case). Capacity } \\
\text { factors are specific for model regions and are estimated for } 6 \\
\text { different wind classes. Values range from } 24-42 \% \text {. Overnight } \\
\text { capital costs are region-specific until } 2030 \text {. Costs decreased } \\
\text { from } 2112 \$ / k W \text { in } 2010 \text { to } 1301 \$ / k W \text { by } 2050(-38 \%) \text { and } \\
1171 \$ / k W \text { by } 2100 \text { (- } 45 \% \text { ). The speed of catching-up by } \\
\text { countries lagging behind varies across narratives and is driven } \\
\text { by GDP development. }\end{array}$ \\
\hline \multicolumn{2}{|c|}{$\begin{array}{l}\text { POLES } \\
\text { Source of documentation: Criqui et al. } 2014\end{array}$} \\
\hline $\begin{array}{l}\text { Recursive dynamic partial } \\
\text { equilibrium model, simulation } \\
\text { model with imperfect foresight }\end{array}$ & $\begin{array}{l}\text { Endogenous technological change. Technologies compete on } \\
\text { LCOE in multinomial logit. } \\
\text { Two-factor learning curve: overnight capital costs are } \\
\text { decreasing proportionally to cumulative capacities (learning } \\
\text { by doing) and to cumulative spending on energy R\&D } \\
\text { (learning by searching). Ex-post calculated learning rates }\end{array}$ \\
\hline
\end{tabular}




\begin{tabular}{|c|c|}
\hline & $\begin{array}{l}\text { range between } 8.9 \text { and } 11 \% \text { for the period } 2010-2030 \text {. Floor } \\
\text { costs limit the decrease. Parameters are calibrated using } \\
\text { historical data. Data are non-linear, which is why two } \\
\text { alternative periods are used (1980-2010 and 1980-2000). }\end{array}$ \\
\hline \multicolumn{2}{|c|}{$\begin{array}{l}\text { WITCH } \\
\text { Source of documentation: https://doc.witchmodel.org/wind-power.html (accessed: 11.1.2019) }\end{array}$} \\
\hline $\begin{array}{l}\text { General equilibrium growth } \\
\text { model, inter-temporal } \\
\text { optimization with perfect } \\
\text { foresight, non-linear } \\
\text { representation of the energy } \\
\text { system }\end{array}$ & $\begin{array}{l}\text { Endogenous technological change. Technologies compete on } \\
\text { LCOE basis in a nested constant elasticity of substitution (CES) } \\
\text { system with medium flexibility. } \\
\text { Distinguishes nine wind classes. Base year investment costs } \\
\text { range from } 2641 \mathrm{USD} / \mathrm{kW} \text { (for shallow installations) to } 2861 \\
\text { USD/kW (transitional) and } 3081 \mathrm{USD} / \mathrm{kW} \text { (for deep } \\
\text { installations). Lifetime of plants is } 30 \text { years. Costs for } \\
\text { operation and maintenance are twice as high as for onshore } \\
\text { (25-30 \$/kW). Investment costs decrease at a learning rate of } \\
13 \% \text {. Cross-learning between onshore and offshore installed } \\
\text { capacity has a rate of } 80 \% \text {, Floor costs are set at } 900 \text { USD/kW. }\end{array}$ \\
\hline
\end{tabular}

Table 1 : Sample of IAM that cover offshore wind deployment explicitly.

Source: various sources and https://www.iamcdocumentation.eu/index.php/IAMC wiki

One model assumes exogenous technological change (MESSAGE), whereas the other IAM feature endogenous technological change. In all models, technologies compete on the basis of LCOE and a decline in investment costs with increased experience (measured by capacities installed) is assumed. This development is known as "learning-by-doing". Connected learning rates vary in the models, ranging from $7 \%$ (IMAGE) to $13 \%$ (WITCH). The models have used harmonized regional specifications and capacity factors (Eurek et al. 2017). Thus, investment costs are also differentiated between classes of offshore power plants. The idea behind this concept is to account for cost dependence on distance from shore, water depth or foundation technology. POLES features a two-factor learning curve, implying that in addition to learning-by-doing, investment costs decrease due to learning-by-(re)searching. Some models also incorporate floor costs as part of the development of investment costs and this is a concept that helps prevent the costs from falling below a threshold. WITCH is an example for an IAM that includes cross-learning between onshore and offshore installed capacities at a rate of $80 \%$, while MESSAGE only assumes across-the board cost reduction for 'non-bio renewables' altogether. Corresponding learning rates depend on the respective scenario. The learning rates used by IMAGE are based on the development of investment costs for offshore wind farms that were built during 1991-2012. In addition to capacity factors and lifetimes of power plants, there are other factors in the models that influence the development of LCOE. For example, the choice for wind offshore as a variable renewable energy is also a function of the diffusion of storage technologies, grid investments and policy incentives. In addition, models show different feedback related to technological change. However, for the sake of simplicity we refrain here from discussing these and refer to Pietzcker et al. 2017. 


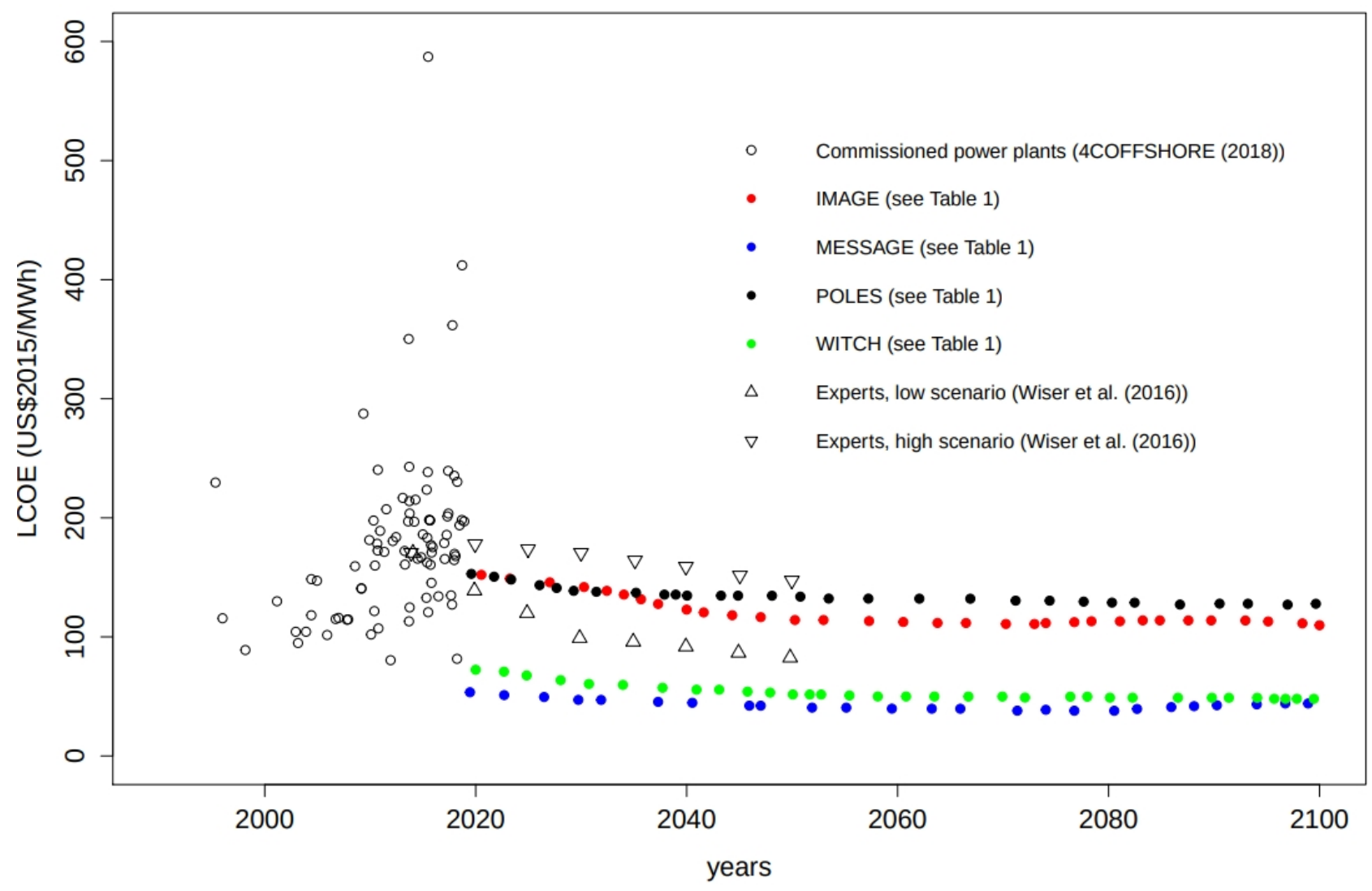

Figure 3: Historic and modelled LCOE

Sources: See figure. Historic LCOE calculated with lifetime of 20 years, discount rate of 10\% following Wiser et al. 2016.

Figure 3 compares the development of LCOE for commissioned wind offshore power plants (collected from 4COffshore database) and how they are projected by experts (Wiser et al. 2016) and the four IAM (see Table 1). What can be learned from comparing model results with observational data, expert knowledge and other models?

- The transition from historical data based on commissioned offshore power plants is not smooth. LCOE might even continue to increase if only observational data of commissioned power plants are considered.

- Overall, cost developments are seen as very optimistic by the experts as well as by the modelling teams. Indeed, none of them anticipates a stagnation or an increase in offshore wind LCOE over the next decades. In particular, all IAM assume a strong improvement in the capacity factor as well as declining investment costs triggered through learning-by-doing. Both have a significant impact on the development of LCOEs. For example, IMAGE motivates the learning rates from development that has been seen for investment costs of onshore wind. However, offshore wind technology is a different technology because it is more complex. Moreover, complexity has been growing as have the investment costs of commissioned offshore power plants (see also Schwanitz and Wierling 2016). Figure 4 presents data for the development of capacity factors as well as investment costs from 1995-2018. The observational data confirm that the models are too optimistic. Up to now, it is not clear if and when those factors show saturation followed by a decline, eventually aligning with the optimistic expectations. Nuclear technology is an example for a continued increase in investment costs with time due to growing complexity (Grubler et al. 2010). It can be concluded that it is necessary to also explore less optimistic scenarios to understand the impact on IAM results in different policy scenarios. 
- There is a discrepancy between the models, with WITCH and MESSAGE reporting LCOE at lower levels compared to IMAGE and MESSAGE. Based on accessible model documentation this offset cannot be explained by third parties.

- Rationales for the choice of parameters are either missing or scarce (e.g. for assumptions about the development of capacity factors, investment costs, and lifetimes).

- Overall, model documentation needs to be improved. Information is spread across many sources and it is difficult for third parties to obtain the necessary details to scrutinize the models. Furthermore, the documentation provided through the Integrated Assessment Modelling Consortium (IAMC) differs with documentation provided by the modelling teams or within publications.

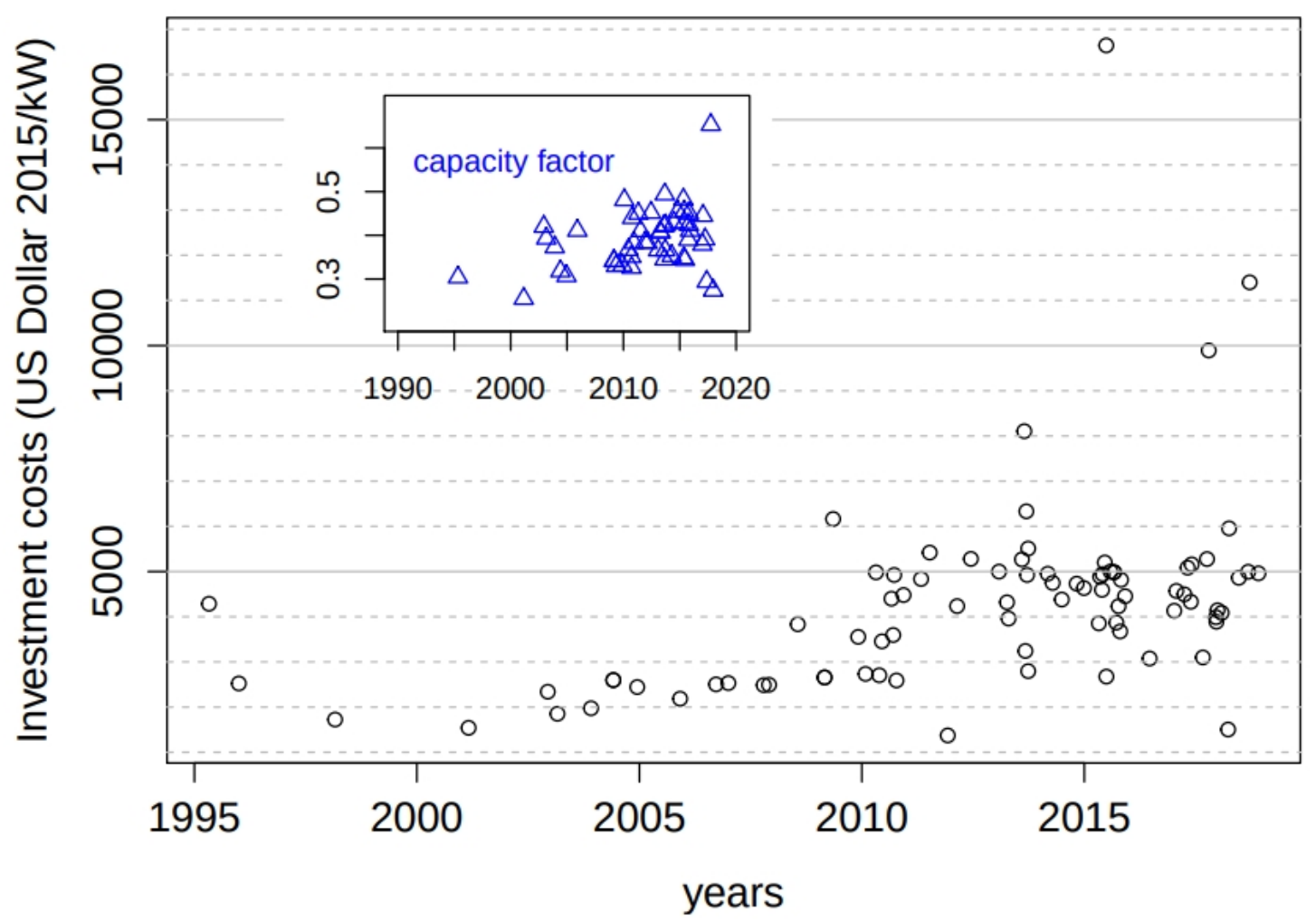

Figure 4 : Investment costs of commissioned offshore wind power plants 1995-10/2018 Sources: 4Cdatabase, own figure, calculation of monetary values using inflation rates from fxtop.com.

\subsection{A note of caution}

The evaluation exercise revealed an optimism bias regarding the deployment of wind offshore technology. This holds not only for IAM modelling teams but also for experts and suggests that we should be cautious with assumptions about future technology developments and it is necessary to regularly question established knowledge. This is particularly important as a validated IAM does not exist, as discussed above.

To iterate this further, the following example can serve as an exemplary lesson, showing that we can be completely wrong about what is considered to be "established" knowledge. In the 1960s, experiments to seed hurricanes were carried out in the USA (c.f. Gentry 1969). The idea was that by putting particles into the eye of a hurricane, one could influence where the hurricane would land. The aim was to steer the hurricane into the direction of less populated areas or back towards the ocean. The hurricane-seeding theory was commonly accepted among scientists, because the theory was confirmed by small scale experiments and even by computer simulations. In addition, four actual seeding experiments with military airplanes were undertaken and the hurricanes changed their directions as expected according to the theory. Backed up by this evidence, a 
large-scale research program was established, but the success in steering the hurricanes could not be repeated and after a few years the program was abandoned. It was only in 1982 that a paper was published shedding light on the issue. In the Bulletin of the American Meteorological Society, Willoughby et al. stated: "Stormfury - as the first seeding experiments were called - itself, however, had two fatal flaws: it was neither microphysically nor statistically feasible. The theory turned out to be wrong and all the evaluation exercises undertaken were not able to detect the scientific errors". In other words, all agreement between theory and experiments was nothing but a coincidence. Luckily, just a couple of million dollars were lost and no one was hurt.

The lesson learnt is particularly relevant in view of current ideas with geoengineering to counter global climate change. For example, solar radiation management (i.e. the spreading of stratospheric sulfate aerosols or other particles to reflect sunlight) has been cited as an attractive, simple solution that costs "just pennies" (PANEL ON POLICY IMPLICATIONS OF GREENHOUSE WARMING (1992)). Whereas efforts to fundamentally transform our societies are much higher in costs, accumulating to a few percent of global GDP (IPCC 2014). These proposed experiments are not just concerned with seeding a single hurricane, but seeding vast clouds around the equator. Similar to the Stormfury operation, the option of solar radiation management has undergone a variety of tests:

- Computer modelling \& multi model intercomparisons: with climate models (e.g. GeoMIP by Kravitz 2013) and IAM (e.g. Goes, Tuana, and Keller 2011; Bickel \& Agrawal 2013). These include the comparison with observational data gathered from volcanic eruptions.

- Cost-benefit analysis: using stylized economic models, incl. decision making under uncertainty and real option analysis (Barrett 2008, Simon et al. 2011, Klepper \& Rickels 2012, McClellan et al. 2012, Bahn et al. 2015)

- Structured expert judgements: e.g. IPCC workshop in 2011 and references therein (IPCC 2011)

- Multi-criteria \& context-first analysis: e.g. Multi Criteria Mapping, Climate Informed Decision Analysis, Stakeholder Decision Analysis, Scenario Analysis, Robust Decision Making (refer to Hall 2012, Hallegatte et al. 2012, and Bellamy 2013)

The tests appear to be very convincing, considering that the models cannot be validated. However, the key question for evaluation is: Are the models able to capture all consequences of deploying a promising technology? Is confidence high enough to gamble on irreversible consequences for the planet? Note that before NASA sends to space, officials have to sign that they bet on the life of the staff sent. What do IAM modelers need to sign?

\section{REFERENCES}

4COFFSHORE (2018), Global offshore wind farms database, http://www.4coffshore.com/windfarms/.

BAHN O., CHESNEY M., GHEYSSENS J., KNUTTI R., PANA A.C. (2015), Is there room for geoengineering in the optimal climate policy mix? Environmental Science \& Policy, 48, 67-76.

BARRETT S. (2008), The incredible economics of geoengineering, Environmental Resource Economics, 39, 45-54.

BELLAMY R., CHILVERS J., VAUGHAN N.E., LENTON, T.M. (2013), 'Opening up' geoengineering appraisal: Multi-Criteria Mapping of options for tackling climate change, Global Environmental 
BICKEL J.E, AGRAWAL S. (2013), Reexamining the economics of aerosol geoengineering, Climatic Change, 119, 993-1006.

CRIQUI P., MIMA S., MENANTEAU P., KITOUS A. (2014), Mitigation strategies and energy technology learning: An assessment with the POLES model, Technological Forecasting and Social Change, 90, 119-136.

EUROPEAN COMMISSION COM(2018) 773 final, Communication from the commission to the European parliament, the European council, the council, the European economic and social committee, the committee of the regions and the European investment bank - A Clean Planet for all, A European strategic long-term vision for a prosperous, modern, competitive and climate neutral economy.

FRICKO O., HAVLIK P., ROGELJ J., KLIMONT Z., GUSTI M., JOHNSON N., KOLP P., STRUBEGGER M., VALIN H., AMANN M., ERMOLIEVA T., FORSELI N., HERRERO M., HEYES C., KINDERMANN G., KREY V., MCCOLLUM D.L., OBERSTEINEr M., PACHAURI S., RAO S., SCHMID E., SCHOEPP W., RIAHI K. (2017), The marker quantification of the Shared Socioeconomic Pathway 2: A middle-of-the-road scenario for the 21st century, Global Environmental Change, 42, 251 - 267.

GENTRY R. C. (1969) Project STORMFURY, Bulletin of the American Meteorological Society 50, 404-409.

GERNAAT D.E.H.J, VAN VUUREN D.P., VAN VLIET J., SULLIVAN P., ARENT D.J. (2014), Global long-term cost dynamics of offshore wind electricity generation, Energy, 76, 663 - 672.

GOES M., TUANA N., KELLER K. (2011), The economics (or lack thereof) of aerosol geoengineering, Climatic Change, 109, 719-744.

GRUBLER A. (2010), The costs of the French nuclear scale-up: A case of negative learning by doing, Energy Policy, 38, 5174-5188.

HALL J.W., LEMPERT R.J., KELLER K., HACKBARTH A., MIJERE C., MCINERNEY D J. (2012), Robust Climate Policies Under Uncertainty: A Comparison of Robust Decision Making and Info-Gap Methods, Risk Analysis, 32, 1657-1672.

HALLEGATTE S., SHAH A., LEMPERT R., BROWN C., GILL S. (2012), Investment Decision Making Under Deep Uncertainty : Application to Climate Change, Policy Research Working Paper, No. 6193, World Bank.

IPCC (2012) Meeting Report of the Intergovernmental Panel on Climate Change Expert Meeting on Geoengineering [O. Edenhofer, R. Pichs-Madruga, Y. Sokona, C. Field, V. Barros, T.F. Stocker, Q. Dahe, J. Minx, K. Mach, G.-K. Plattner, S. Schlömer, G. Hansen, M. Mastrandrea (eds.)]. IPCC Working Group III Technical Support Unit, Potsdam Institute for Climate Impact Research, Potsdam, Germany, pp. 99.

IPCC (2014) Climate Change 2014: Synthesis Report. Contribution of Working Groups I, II and III to the Fifth Assessment Report of the Intergovernmental Panel on Climate Change [Core Writing Team, R.K. Pachauri and L.A. Meyer (eds.)]. IPCC, Geneva, Switzerland, 151 pp. 
JOHNSON N., STRUBEGGER M., MCPHERSON M., C. PARKINSON S., KREY V., SULLIVAN P. (2017), A reduced-form approach for representing the impacts of wind and solar PV deployment on the structure and operation of the electricity system, Energy Economics, 64, 651-664.

JUNGINGER M., VAN SARK W., FAAIJ A. (2010), Technological Learning in the Energy Sector, Lessons for Policy, Industry and Science, Edward Elgar Publishing.

KONIKOV L.F., BREDEHOEFT J.D. (1992), Ground-water models cannot be validated, Advances in Water Resources, 15, 75 - 83.

KLEPPER G., RICKELS W. (2012), The Real Economics of Climate Engineering, Economics Research International, 2012, 316564, 1-20.

KRAVITZ B., ROBOCK A., BOUCHER O., SCHMIDT H., TAYLOR K.E., STENCHIKOV G., SCHULZ M. (2011), The Geoengineering Model Intercomparison Project (GeoMIP), Atmospheric Science Letters, 12, 162-167.

KRIEGLER E., PETERMANN N., KREY V., SCHWANITZ V.J., LUDERER G., ASHINA S., BOSETTI V., EOM J., KITOUS A., MÉJEAN A., PAROUSSOS L., SANO F., TURTON H., WILSON C., VAN VUUREN D.P. (2015), Diagnostic indicators for integrated assessment models of climate policy, Technological Forecasting and Social Change, 90 A, 45-61.

LUDERER G., PIETZCKER R.C., CARRARA S., DE BOER H.S., FUJIMORI S., JOHNSON N., MIMA S., ARENT D. (2017), Assessment of wind and solar power in global low-carbon energy scenarios: An introduction, Energy Economics, 64, 542-551.

MCCLELLAN J., KEITH D.W., APT J. (2012), Cost analysis of stratospheric albedo modification delivery systems, Environmental Research Letters, 7, 034019.

O'NEILL B.C., KRIEGLER E., EBI K.L., KEMP-BENEDICT E., RIAHI K., ROTHMAN D.S., VAN RUIJVEN B.J., VAN VUUREN D.P., BIRKMANN J., KOK K., LEVY M., SOLECKI W. (2016), The roads ahead: narratives for Shared Socioeconomic Pathways describing world futures in the 21st century, Global Environ. Change, 42, 169-180.

PANEL ON POLICY IMPLICATIONS OF GREENHOUSE WARMING (1992), Policy implications of greenhouse warming: mitigation, adaptation, and the science base, National Academy Press.

PIETZCKER R.C., UECKERDT F., CARRARA S., DE BOER H.S., DESPRÉS J., FUJIMORI S., JOHNSON N., KITOUS A., SCHOLZ Y., SULLIVAN P., LUDERER G. (2017), System integration of wind and solar power in integrated assessment models: a cross-model evaluation of new approaches, Energy Economics, 64, 583-599.

POYNTER J. (2006), The Human Experiment: Two Years and Twenty Minutes Inside Biosphere 2, Basic Books.

RIAHI K., VAN VUUREN D.P., KRIEGLER E., EDMONDS J., O'NEILL B.C., FUJIMORI S., BAUER N., CALVIN K., DELLINK R., FRICKO O., LUTZ W., POPP A., CUARESMA J.C., KC S., LEIMBACH M., JIANG L., KRAM T., RAO S., EMMERLING J., EBI K., HASEGAWA T., HAVLIK P., HUMPENÖDER F., ALELUIA DA SILVA L., SMITH S., STEHFEST E., BOSETTI V., EOM J., GERNAAT D., MASUI T., ROGELJ J., STREFLER J., DROUET L., KREY V., LUDERER G., HARMSEN M., TAKAHASHI K., BAUMSTARK L., DOELMAN J.C., KAINUMA M., KLIMONT Z., MARANGONI G., LOTZE-CAMPEN H., OBERSTEINER M., TABEAU A., 
TAVONI M. (2017), The Shared Socioeconomic Pathways and their energy, land use, and greenhouse gas emissions implications: An overview, Global Environmental Change, 42, 153-168.

SARGENT R.G. (2003), Verification and validation: verification and validation of simulation models in CHICK S., SANCHEZ P.J., FERRIN D., MORRIS D.J. (eds.), Proceedings of the 2003 Winter Simulation Conference, IEEE.

SCHWANITZ V.J. (2013), Evaluating integrated assessment models of global climate change, Environmental Modelling \& Software, 50, 120-131.

SCHWANITZ V.J., WIERLING A. (2016), Offshore wind investments - Realism about cost developments is necessary, Energy, 106, 170-181.

SIMON A.J., KAAHAAINA N.B., FRIEDMANN S.J., AINES, R.D. (2011), Systems analysis and cost estimates for large scale capture of carbon dioxide from air, Energy Procedia, 4, 2893-2900.

VAN SLUISVELD M.A.E, HARMSEN M.J.H.M., VAN VUUREN D.P., BOSETTI V., WILSON C., VAN DER ZWAAN B. (2018), Comparing future patterns of energy system change in $2{ }^{\circ} \mathrm{C}$ scenarios to expert projections, Global Environmental Change, 50, 201-211.

WILLOUGHBY H.E., JORGENSEN D.P., BLACK R.A., ROSENTHAL S.L. (1985), Project STORMFURY: A Scientific Chronicle 1962-1983, Bulletin American Meteorological Society, 66, 505-514.

WILSON C., KRIEGLER E, VAN VUUREN D.P., GUIVARCH C., FRAME D., KREY V., OSBORN T.J., SCHWANITZ V.J., et al. (2017). Evaluating Process-Based Integrated Assessment Models of Climate Change Mitigation, IIASA Working Paper.

WISER R., JENNI K., SEEL J., BAKER E., HAND M., LANTZ E., SMITH A. (2016), Expert elicitation survey on future wind energy costs, Nature Energy, 1, 16135. 